\title{
The role of the European Academy of Teachers in General Practice and Family Medicine in family medicine education in Europe - the experience of the University of Maribor
}

\author{
Zalika Klemenc-Ketiš, Janko Kersnik \\ Department of Family Medicine, Medical \\ School, University of Maribor, Slovenia \\ Corresponding author: \\ Zalika Klemenc-Ketiš \\ Kersnikova 1 \\ 3320 Velenje \\ Slovenia \\ zalika.klemenc-ketis@uni-mb.si \\ Tel.: + 38638963122 \\ Fax: + 38638963119
}

Received: 30 November 2011

Accepted: 16 January 2012

Copyright (C) 2012 by

Academy of Sciences and Arts

of Bosnia and Herzegovina.

E-mail for permission to publish:

amabih@anubih.ba

\begin{abstract}
Primary health care is important item of political agendas since Alma Ata conference in 1978. West Balkans share common history in development of primary care since 1920' when Andrija Stampar introduced social and community based primary care concepts. The first known specialist training in general practice in the world started in former Yugoslavia in the early 1960'. Since then, much has been done in the field of general practice and family medicine and this is reflected in The European Academy of Teachers in General Practice and Family Medicine (EURACT), which is a network organisation within World Organization of National Colleges, Academies and Academic Associations of General Practitioners/Family Physicians Region Europe (WONCA Europe). Its aim is to foster and maintain high standards of care in European general practice by promoting general practice as a discipline by learning and teaching. EURACT developed several documents and teachers' courses which can serve the development of family medicine curricula in new established departments of medical schools. This is also the case at Maribor Medical School, where learning outcomes and teaching methods are in concordance with EURACT teaching agenda, but also some innovative approaches are used, such as art and e-learning environment as teaching methods.
\end{abstract}

Key words: Family practice, Education, Europe, Slovenia.

\section{Introduction}

Primary health care is high on the agenda of all WHO countries in the world since Alma Ata conference in 1978 (1). We could say that we are again facing the same dilemmas as our colleagues were facing in the early 1920, when in nearly identical circumstances prominent public health experts claimed the importance of equity, accessibility and affordability of preventive and curative medical interventions to the benefit of the whole populations, not only those, who were able to pay for it.

\section{Short history of family medicine in Europe and former Yugoslavia}

Andrija Stampar, World Health Organisation expert, was one of the leading minds in that time and had left the legacy in the form of integrated primary care institutions and the first known specialist training in gen- 
eral practice in the world, which started in former Yugoslavia in the early 1960' $(2,3)$. With the rare exceptions (4) primary care as the basis of health care service delivery still remains only a popular phrase in politicians' public speeches and dialogues. One of the key persons in today public health care discussions was Barbara Starfield, who succeeded to provide studies on importance of primary care and family practice (FP) (5). She claimed that an orientation to primary care reduced socio-demographic and socioeconomic inequities in access to health services and in population health. FP has to deliver evidence based care and has to serve its patients as the first contact with health care services, its population as the comprehensive service from promotion of health to palliation of the incurable diseases and its nation as the most rational use of the available resources. FP has its unique task profile, which cannot be assumed as a simple addition of the task profiles of other disciplines taught in Medical Schools (6-8). European Union Directive demands from that member states must introduce specialty training in family medicine of minimum 3 years duration $(9,10)$. An important contribution to this is traditional social dimension of health care systems in the countries established from Former Yugoslavia $(3,11)$.

\section{Development of EURACT}

General practice/family medicine is probably the only medical discipline, which spends so much time on defining its field, boundaries, competences and task profile $(12,13)$. Partly, this can be ascribed to the fact that once upon a time there was only one medicine existed - general medicine, which cared for the patients in a holistic, comprehensive, community oriented and ethically correct way. By extraction of many specialist braches, the discipline floated on the surface of the second part of $20^{\text {th }}$ cen- tury's events. The European Academy of Teachers in General Practice and Family Medicine (EURACT) is a network organisation within World Organization of National Colleges, Academies and Academic Associations of General Practitioners/Family Physicians Region Europe (WONCA Europe) WONCA Region Europe - ESGP/FM and was launched in March, 1992 to support teachers in FP to provide the best care for the populations. The establishment of the European Academy of Teachers in General Practice can be traced back to the formation of the first Leeuwenhorst Group in 1974. This group acted as a workshop for developing new ideas on the teaching of general practice, and is remembered for defining the role of the general practitioner and this definition remains valid today. Its successor was the New Leeuwenhorst Group, which was formed in 1982 and was concerned with the further development of general practice as a discipline by teaching and learning. The overall aim of the EURACT is to foster and maintain high standards of care in European general practice by promoting general practice as a discipline by learning and teaching (14-16). EURACT has developed a definition of general practice (17), which was adopted by WONCA, and already served as a basis for the development of educational and research agenda (18-20).

\section{Basic medical education}

In Medical Schools at university level, family medicine is taught in almost all European countries with the established Departments, and sometimes also in the Medical Schools without department of general practice. The curricula are sometimes organised only as residency programmes in general practice following basic medical education, but mainly as a separate subject during the main medical curricula. The absence of some form of teaching about general practice in 
basic medical education (BME) is in Europe merely an exception to the rule. According to the definitions of the profession, family medicine has a lot to offer to the common knowledge and skill base of Medical Schools' students (21). The students can learn important concepts, which they can use in their future medical careers, i.e. communication skills, primary care approach, community orientation, working in the community settings, etc., and can not be taught during other curricula. They can learn the provision of health care directly from the primary care practices, communities, visiting nurses and other primary care providers.

\section{Specialist training}

Specialist (vocational) training for general practice has become a rule in the majority of European countries (22). Several options are in place on how to provide "in service training" for those already working in general practice and how to retrain physicians from other specialities to practice as family doctors. Developed countries are taking the lead in designing the curricula which should reflect the needs of their populations (23). A special task force group in EURACT is working on Performance Agenda based on European Definition and Educational Agenda. Canada (24), USA and Denmark have some advances in this field, which will be incorporated into the final EURACT document.

Other important areas are selection of candidates for trainees and selection of trainers and training practices. Also in this field, EURACT acts proactively in providing guidance to governments and other responsible bodies $(19,25)$.

\section{Continuing medical education}

Continuing medical education was traditionally regarded as a key feature in quality assurance. There is a wide variation in re- certification, continuing medical education (CME) and continuing professional development among the European countries (26). Recently, there was a shift from large CME activities towards small group learning, individual learning plans and use of modern technologies, which enables more personalised approach to learning. In the universities the selection of teaching methods and the pedagogic (i.e. teaching) competences of the teachers are often neglected, emphasising mainly research achievements of the candidates. Traditionally, the curricula depend on classroom lectures and direct observation of practice based activities instead on the advanced methods, which take into the account students' learning cycle. However, family medicine departments are on the lead in teaching and using modern methods (21). In order to prove themselves they also use and spread new methods among the rest of the faculty, therefore improving the whole teaching process in Medical Schools (27).

Besides exchange of the experiences, reports $(22,25)$ ideas, educational materials, EURACT produces documents (17-19, 23 ), and different level of courses for novice, proficient and expert teachers to fill this gap (28). Similarly, international course on assessment in medicine is aiming at the educators at undergraduate and postgraduate level and wants to deliver basic knowledge and skills in modern assessment methods. EURACT - "Bled" course teaching the teachers, which started in Slovenia in 1992, holds a special place amongst EURACT courses. Each year we deal with a new theme important for general practice, for example community orientation, communication skills, patient empowerment, medical error, medical ethics, quality assurance, practice management, etc. (29). 


\section{Teaching family medicine at Maribor University in Slovenia}

\section{Curriculum}

At the Maribor University, undergraduate study of medicine lasts for six years. Family medicine is taught in the fourth and sixth year of study (seventh and $11^{\text {th }}$ semester). Main themes, included in the curriculum of both semesters correspond to key features of family medicine (Box 1).

Box 1. Main themes in the curriculum of both semesters in Maribor Medical School.

- Use of clinical knowledge in early clinical exposure

- Doctor-patient communication and relationship

- Community orientation

- Practice management

\section{Learning outcomes}

During family medicine programme (both in fourth and sixth year of study), students are expected to gain knowledge, skills and attitudes (Table 1), which are in concordance with EURACT teaching agenda (18).

\section{Teaching methods}

The curriculum of family medicine consists of lectures, seminars, and exercises. While lectures and seminars are well-defined methods and allow little modifications, appropriate teaching methods as defined in EURACT educational agenda (18) are employed during exercises. Teaching methods are in correlation with learning outcomes (Table 1).

\section{Lectures}

Lectures take place only in the fourth year of study. Because they are regarded as having low educational value (30), but are an obligatory part of family medicine curricu- lum due to Maribor Medical School's rules, other teaching methods are applied during lectures. These are discussions, buzz-groups, and reflections. Also, lectures are interactive and based on real clinical cases. These methods give additional educational value (31) to lectures and enable students to participate actively.

\section{Seminars}

Students in both study years must write an essay and present it orally in front of their colleagues and teacher, which is followed by a discussion, lead by a teacher. Forth-year students choose a theme (usually a common medical problem or disease) and write about it from an angle of primary care approach. The structure of such essay is in form of a review article. Sixth-year students choose a real patient case during clinical work in family medicine practice. They are encouraged to choose patients with common medical problems or diseases as well. The structure of such essay is in a form of a case report, a part of which is also a clinical question, posed by students themselves. They should answer it on the basis of evidence-based medicine (32). Other teaching methods, employed in seminars, are literature search, reading, and writing.

\section{Exercises}

Exercises consist of learning about family and family dynamics, learning about primary care approach, learning about communication, learning about house visits, solving problems in virtual practice, ordering laboratory tests, ordering physical therapy, skills training on models, working in clinical practice under tutor's supervision, and field work. During exercises we use following teaching methods: clinical work in clinical practice under supervision, interactive learning, observation, reflection, role playing, project work, skills training, and study visit. 
Table 1 Learning outcomes, teaching methods, and assessment methods in Family Medicine curriculum at the Maribor University, Slovenia

\begin{tabular}{|c|c|c|}
\hline Learning outcomes & Teaching methods & Assessment methods \\
\hline $\begin{array}{l}\text { Knowledge } \\
\text { - Be familiar with primary care approach } \\
\text { in management of patients' health care } \\
\text { problems } \\
\text { - Know the importance of doctor-patient } \\
\text { relationship in family medicine } \\
\text { - Be able to define comprehensive and } \\
\text { holistic approach to patients } \\
\text { - Be able to define person-centred care } \\
\text { - Be able to define primary care approach in } \\
\text { diagnosing and treating patients } \\
\text { - Know the importance of community } \\
\text { orientation } \\
\text { - Know the importance of continuity of care } \\
\text { - Know the importance of communication in } \\
\text { management of patients } \\
\text { - Be familiar with team work and members of } \\
\text { family doctor's team }\end{array}$ & $\begin{array}{l}\text { Lecture, essays, oral presentation, } \\
\text { discussion, clinical work, literature search, } \\
\text { reading, study visit, project work, video, } \\
\text { educational movies }\end{array}$ & $\begin{array}{l}\mathrm{MCQ}^{*}, \mathrm{MEQ}^{* *} \text {, essays, } \\
\text { oral method }\end{array}$ \\
\hline $\begin{array}{l}\text { Skills } \\
\text { - Use clinical knowledge in early clinical } \\
\text { exposure } \\
\text { - Use empathy } \\
\text { - Communicate with patients } \\
\text { - Run a consultation } \\
\text { - Keep patient records } \\
\text { - Work safely and improve quality } \\
\text { - Perform a home visit } \\
\text { - Use primary care approach in diagnosing } \\
\text { and treating patients } \\
\text { - Work in a team. }\end{array}$ & $\begin{array}{l}\text { Role playing, clinical work, observation, } \\
\text { reading, skills training }\end{array}$ & OSCE ${ }^{* * *}$, role playing \\
\hline $\begin{array}{l}\text { Attitudes } \\
\text { - Understand the families in health and } \\
\text { disease } \\
\text { - Understand the importance of continuity of } \\
\text { doctor-patient relationship in primary care } \\
\text { - Understand the importance of } \\
\text { communication skills } \\
\text { - Understand the importance of } \\
\text { comprehensive and holistic approach } \\
\text { - Understand the importance of person- } \\
\text { centred care } \\
\text { - Understand the importance of community } \\
\text { orientation } \\
\text { - Value the importance of multiprofessional } \\
\text { care }\end{array}$ & $\begin{array}{l}\text { Lecture, essays, oral presentation, } \\
\text { discussion, role playing, clinical work, } \\
\text { observation, project work, video, } \\
\text { educational movies }\end{array}$ & $\begin{array}{l}\mathrm{MCQ}, \mathrm{MEQ} \text {, essays, oral } \\
\text { method, role playing }\end{array}$ \\
\hline
\end{tabular}

Abbreviations: *MCQ - multiple choice questions; ${ }^{* *} \mathrm{MEQ}$ - modified essay questions ; ${ }^{* *} \mathrm{OSCE}$ - objective structured clinical exam.

\section{Assessment methods}

Assessment methods correspond to learning outcomes and teaching methods employed (Table 1). We use both formative and summative assessment (33).
During family medicine programme in the fourth year of study, students are formatively assessed by teachers during several course units: written and oral presentation of an essay, written and oral presentation of 
chosen family, communication assessment (video clip of role playing), solving problems in virtual practice, and skills assessment (MEQ analysis, work in clinical practice settings, clinical skills, field work project report, report about an educational movie). Each course unit is then summatively assessed by teachers on a 6-point Likert scale (0 - unsatisfactory, 5 - excellent). Final mark (summative assessment) is calculated from all course units' scores.

During family medicine programme in the sixth year of study, students are formatively assessed by teachers during several course units: written and oral presentation of a case study (essay), assessment of working in clinical practise settings, assessment of working in nursing home, and assessment of knowledge about health legislation. Each course unit is then summatively assessed by teacher on a 6-point Likert scale (0 - unsatisfactory, 5 - excellent). At the end of the family medicine course in the sixth year of study, students must pass a written exam, which consists of 50 MCQ questions. Final mark (summative assessment) is calculated from all course units' scores and score from a written exam.

\section{Teaching materials (sources)}

Family medicine education on Maribor University is based on three textbooks (34-36), written by teachers at the Department of Family Medicine. Each year, we also publish new editions of instructions for teachers (37), instructions for students (38) and instructions for essays' writing (39).

Other teaching materials (articles, examples of books, forums, e-modules) can be found at e-learning environment Moodle (40) and at the Department of Family Medicine Maribor's web page (41). These pages are regularly updated.

\section{Educational research}

Teachers at the Department of Family Medicine in Maribor are also interested in educa- tional research, mainly from the field of new teaching methods. One of such methods, successfully implemented in the teaching process, is using movies in medical education. Movies present developed scenarios and are a form of controlled environment, which enables reproducible, focused and independent student learning. Through art, students are able to understand patients in their whole context (42).

The controlled environment of movies successfully enables students to explore their values, beliefs, and attitudes towards features of professionalism without feeling that their personal integrity had been threatened (27).

\section{Conclusion}

The development of family medicine as part of primary care approach in West Balkans has a long tradition. European academy of teachers, a WONCA Europe network organisation developed several documents and teachers' courses which can serve the development of family medicine curricula in new established departments of medical schools which is also a case at Maribor Medical School. Here, learning outcomes and teaching methods are in concordance with EURACT teaching agenda. Also, some innovative approaches are used, i.e. using art in teaching holistic approach to patients and using e-learning environment for students' project and communication.

Authors' contribution: Conception: JK and ZKK; Drafting the article: ZKK and JK; Revising it critically for important intellectual content: ZKK and JK.

Conflict of interest: The authors declare that they have no conflict of interest. This article was not sponsored by any external organisation.

\section{References}

1. Anon. Declaration of Alma-Ata International Conference on Primary Health Care, Alma-Ata, 
USSR, 6-12 September 1978 [cited 2011 November 25]. Available from: http://www.who.int/hpr/ $\mathrm{NPH} /$ docs/declaration_almaata.pdf.

2. Kersnik J. Progress in Family Medicine in Slovenia. Middle East Journal of Family Medicine [serial on the internet]. 2004 [cited 2011 November 25]. Available from: http://www.mejfm.com/journal/oct03/Slovenia.pdf.

3. Saric M, Rodwin VG. The Once and Future Health System in the Former Yugoslavia: Myths and Realities. J Public Health Policy. 1993;14:220-37.

4. Anon. Short NHS History [cited 2011 November 25]. Available from: http://www.nhshistory.net/ shorthistory.htm.

5. Starfield B. Is primary care essential? Lancet. 1994;344:1129-33.

6. White KL. The ecology of medical care: origins and implications for population-based healthcare research. Health Serv Res. 1997;32:11-21.

7. Ferrer RL, Hambindge SJ, Rose MC. The Essential Role of Generalists in Health Care Systems. Ann Intern Med. 2005;142:691-9.

8. Švab I. General practice teaching at the undergraduate level in Europe. Eur J Gen Pract. 1999;5:125-7.

9. Council directive 93/16/EEC of 5 April 1993 to facilitate the free movement of doctors and the mutual recognition of their diplomas, certificates and other evidence of formal qualifications (OJ L 165, 7.7.1993, p. 1) [cited 2011 November 25]. Available from: http://eur-lex.europa.eu/LexUriServ/ LexUriServ.do?uri=CONSLEG:1993L0016:20070 101:EN:PDF

10. Seifert B, Švab I, Madis I, Kersnik J, Windak A, Steflova A, et al. Perspectives of family medicine in Central and Eastern Europe. Fam Pract. 2008;25:113-8.

11. Švab I, Kersnik J, Klančar D. Health centre: a relict from the past or a vision of the future. Zdrav Var. 2005;44:178-82.

12. Boerma WG, van der Zee J, Fleming DM. Service profiles of general practitioners in Europe. European GP Task Profile Study. Br J Gen Pract. 1997;47:481-6.

13. Svab I, Pavlic DR, Radic S, Vainiomäki. General practice east of Eden: an overview of general practice in Eastern Europe. Croat Med J. 2004;45(5):537-42.

14. Bentzen BG, Bridges-Webb C, Carmichael L, Ceitlin J, Feinbloom R, Metcalf D, et al. The role of the general practitioner/family physician in health care systems: a statement from WONCA; 1991 [cited 2011 November 25]. Available from: http://www.globalfamilydoctor.com/publications/ Role_GP.pdf.

15. Anon. EURACT presentation booklet [cited 2011 November 25]. Available from: http://www.euract. org/html/pdf/booklet2004.pdf.

16. Grol R, Dautzenberg M, Brinkmann H, editors. Quality management in Primary Care. European Practice Assessment. Gütersloh: Verlag Bertelsmann Stiftung; 2004.

17. Allen J, Gay B, Crebolder H, Heyrman J, Svab I, Ram P. The European definition of general practice/family medicine; 2005 [cited 2011 November 25]. Available from: http://www.euract.eu/officialdocuments/finish/3-official-documents/94-european-definition-of-general-practicefamily-medicine-2005-full-version.

18. Heyrman J, editor. The EURACT Educational Agenda of general practice/family medicine; 2005 [cited 2011 November 25]. Available from: http:// www.euract.eu/official-documents/finish/3-official-documents/93-euract-educational-agenda.

19. Wilm S, editor. EURACT Checklist for Attachment Program Organisers: Teaching general practice in the practice setting in basic medical education; 2005 [cited 2011 November 25]. Available from: http://www.euract.eu/others/finish/20others/97-euract-checklist-for-attachment-program-organisers-full.

20. Hummers-Pradier E, Beyer M, Chevallier P, EilatTsanani S, Lionis C, Peremans L, et al. Research Agenda for General Practice / Family Medicine and Primary Health Care in Europe, European General Practice Research Network EGPRN; 2009 [cited 2011 November 25]. Available from: http:// www.egprn.org/images/Research\%20Agenda\%20 for $\% 20$ General\%20Practice_Family\%20Medicine.pdf.

21. Švab I, Bulc M. Academic Medicine: What Does an Outsider Have to Offer? Croat Med J. 2004;45:254-5.

22. Anon. GP/FM specialist training schemes in Europe; 2004 [cited 2007 June 24]. Available from: http://www.euract.eu/resources/specialist-training.

23. Royal College of General Practitioners [homepage on the internet]. London: Royal College of General Practitioners [cited 2007 June 24]. Available from: http://www.rcgp-curriculum.org.uk/.

24. Frank JR, Jabbour M, editors. Report of the CanMEDS Phase IV Working Groups. Ottawa: The Royal College of Physicians and Surgeons of Canada; 2005 [cited 2007 June 24]. Available from: http://www.healthcare.ubc.ca/residency/CanMEDS_2005_Framework.pdf. 
25. Anon. EURACT Statement on Selection of Trainers and Teaching Practices for Specific Training in General Practice Tartu; 2002 [cited 2011 November 25]. Available from: http://www.euract.eu/ others/finish/20-others/99-euract-statement-onselection-of-trainers-and-teaching-practices-forspecific-training-in-general-practice.

26. Anon. Integration of formal CME. EURACT; 2002 [cited 2011 November 25]. Available from: http:// www.euract.eu/others/finish/20-others/102-integration-of-formal-cme-and-quality-improvement-initiatives-2001-policy-document-ofequip-and-euract.

27. Klemenc-Ketis Z, Hladnik Z, Kersnik J. Using movies to teach professionalism to medical students. BMC Medical Education. 2011; 11:60.

28. EURACT Workshops \& Courses [cited 2011 November 25]. Available from: http://www.euract. eu/activities/workshops-courses.

29. Švab I, Yaphe Y, Correia de Sousa J, Passerini G. An international course for faculty development in Family Medicine: the Slovenian model. Med Educ. 1999;33:780-1.

30. Petty G. Teaching Today. Cheltenham: Nelson Thornes; 2001.

31. Matheson C. The educational value and effectiveness of lectures. The Clinical Teacher. 2008;5:218-21.

32. Evidence-Based Medicine Working Group. A new approach to teaching the practice of medicine. JAMA. 1992;2:2420-5.
33. Taras M. Summative and formative assessment. Active Learning in Higher Education. 2008;9:172-92.

34. Kersnik J. Osnove družinske medicine. Maribor: Medicinska fakulteta Univerze v Mariboru; 2007.

35. Klemenc-Ketiš Z, editor. Praktikum družinske medicine. 1. izdaja. Maribor: Medicinska fakulteta Univerze v Mariboru; 2009.

36. Klemenc-Ketiš Z, editor. Praktikum družinske medicine. 2. dopolnjena izdaja. Maribor: Medicinska fakulteta Univerze v Mariboru; 2011.

37. Klemenc-Ketiš Z, editor. Navodila za vaje za asistente, mentorje in učitelje veščin. Maribor : Katedra za družinsko medicine, Medicinska fakulteta; 2011.

38. Klemenc-Ketiš Z, editor. Navodila za vaje za študente. Maribor: Katedra za družinsko medicine, Medicinska fakulteta; 2011.

39. Klemenc-Ketiš Z, Kersnik J. Navodila za pisanje seminarskih nalog za študente. Maribor: Katedra za družinsko medicine, Medicinska fakulteta; 2011.

40. E-learning environment [homepage on the Internet]. Maribor: University of Maribor [cited 2011 November 25]. Available from: https://estudij.uni-mb.si.

41. Drmed.org [homepage on the Internet]. Maribor: Department of Family Medicine [cited 2011 November 25]. Available from: http://www.drmedmb.org/.

42. Blasco PG, Moreto G, Roncoletta AFT, Levites MR, Janaudis MA. Using movie clips to foster learners' reflection: improving education in the affective domain. Fam Med. 2006;38:94-6. 